\title{
Producing the "Highway to Nowhere": Social Understandings of Space in Baltimore, 1944-1974
}

\author{
AMANDA K. PHILlipS DE LUCAS \\ CARY INSTITUTE OF ECOSYSTEM STUDIES
}

\begin{abstract}
The "highway to nowhere" is a 1.32 mile fragment of an arterial expressway located in Baltimore, Maryland. This segment was designed to contribute to a proposed limited access highway system that was never constructed after years of activism, debate, and lawsuits. This article examines the history of the construction of this highway segment to suggest that conflicts over the design, sitting, and construction of infrastructure are fundamentally struggles over the definition and production of space. This analysis utilizes Henri Lefebvre's triad of spatial production as an analytical framework to identify distinct spatial forms that surface during the process of infrastructure building. Utilizing this analytical framework may enrich the STS-based infrastructure inquiries by bringing to the surface the multiple forms of spatial production that structure system-building activities. In conclusion, I suggest that utilizing Lefebvre's triad within studies of infrastructure surfaces important, and potentially transformative, local claims to space. Such claims are of renewed importance as cities across the US confront the segregationist histories of the built environment.
\end{abstract}

\section{Keywords}

infrastructure; Baltimore; highways; Henri Lefebvre; social production of space

\section{Introduction}

In 1973, following years of activism, community organizing, and lawsuits, construction began on what would become 1.32 miles of arterial highway in west Baltimore. The segment, unlike other express highways, directly flows to collector streets at its eastern and western termini. City residents refer to the chasm of concrete bisecting the neighborhoods of Harlem Park and Franklin Square as the "highway to nowhere." Baltimore's history of redlining, urban renewal, and restrictive covenants has produced a city racially, ecologically, and economically segregated (Brown 2015; Light 2009; Locke et al. 2019; Pietila 2010). The highway to nowhere, dividing two

'Amanda K. Phillips de Lucas, Email: phillipsa@caryinstitute.org

Copyright ( 2020 (Amanda K. Phillips de Lucas). Licensed under the Creative Commons Attribution Non-commercial No Derivatives (by-nc-nd). Available at estsjournal.org. 
predominantly Black and economically impoverished neighborhoods, serves as a powerful testament to the role of infrastructure in the deliberate fracturing of cities.

A road segment, divorced from a larger arterial system, was not the desired outcome imagined by Baltimore's engineers, planners, and leaders of decades past. When comprehensive highway planning first began in the 1940s, professionals imagined efficient ribbons of roads directing suburban commuters and consumers into and around the city. Building highway infrastructure was seen as a concrete solution for cities facing declining residential populations and tax revenues associated with suburban sprawl (Rose and Mohl 2012). Additionally, planners positioned infrastructure construction as a fix to urban problems such as housing density, blight, and crime (Lieb 2018; Moses 1945). These goals, creating efficient routes for suburban residents and clearing blight, were simultaneously assertions of how city space ought to be used and by which populations.

That the city of Baltimore supported the goal of displacement, specifically of residents both Black and poor, was not lost to the inhabitants of West Baltimore neighborhoods such as Harlem Park, Rosemont, Edmondson, and Franklin Square. Indeed, activists from these neighborhoods described the proposed arterial route as a technology that would eliminate their ability to live in, access, and contribute to the city. Displacement amounted to erasure. Despite this understanding, activists did not always position themselves against highway construction. Instead, the demands of activists emerged out of a confluence of spatial practices--the landscape transformation proposed by engineers and planners, the lived, day-to-day experience of residents, and importantly, the future spaces activists imagined possible. These differential understandings and articulations of the impacts of infrastructure within neighborhoods point to the importance of surfacing matters of spatial production in conflicts over proposed systems.

This article draws from archival sources-minutes from meetings with activists, planning documents, and newspaper articles-to suggest that conflicts over the design, sitting, and construction of infrastructure are fundamentally struggles over the definition and production of space. The highway to nowhere, as both a material fragment of a once proposed larger system and a planning abstraction that was imagined to alter city space, offers a case to examine how the production of space informs both social structures and technological forms. This analysis utilizes Henri Lefebvre's triad of spatial production--spatial practice, representations of space, and representational space--as an analytical framework to identify distinct spatial forms that surface during the process of infrastructure building (Lefebvre 1991). Drawing from this framework may enrich Science and Technology Studies (STS)-based infrastructure inquiries by bringing to the surface the modes of spatial production that undergird system-building activities.

The following section introduces and describes the modes of spatial production articulated in Lefebvre's analytical framework. Further, this section identifies where the analytical framework intersects with existing literature in STS-based approaches to studying infrastructure. Section 3 draws from archival documents to identify how city officials and planners in the 1940s viewed an arterial highway as capable of transforming the productive capacities and socio-demographic characteristics of Baltimore. These representations of space, introduced by Robert Moses, paired highway construction in the Franklin-Mulberry Corridor in 
West Baltimore to a larger project of segregationist spatial transformation. This section describes how Moses and other highway planners positioned infrastructural transformation, articulated the ideology that guided plans, and manufactured knowledge to justify system building.

Section 4 moves forward in time to the late 1960s when West Baltimore residents formed an organization, Relocation Action Movement (RAM), to advocate for neighborhood involvement in highway plans. This section demonstrates how social forms emerged in response to proposed representations of space proffered by engineers and officials. By identifying the spatial practices and representational spaces that structured resistance efforts, this section demonstrates how activists paired knowledge and power at a neighborhood scale. In conclusion, I suggest that utilizing Lefebvre's triad within investigations of infrastructure surfaces important, and potentially transformative, local claims to space. Such claims are of renewed importance as cities across the US confront segregationist histories of the built environment.

\section{2 - Spatial Production, Infrastructure, and Imagination}

This section begins by introducing Lefebvre's triad of spatial production as an analytical framework. Following the general introduction, I point to places of overlap between the framework and existing literature emerging from STS-based approaches to infrastructure studies. The section concludes by addressing possible limitations and critiques that might emerge from using this framework within studies of infrastructure.

\section{1 - The Conceptual Triad of Spatial Production}

Henri Lefebvre, a Marxist philosopher and social theorist, first developed a theory of spatial production in his 1974 book, Le Production de l'espace, (The Production of Space). In 1991, the text was translated into English, extending its circulation beyond a francophone audience. Despite the books' vintage, contemporary scholars in geography (Blomley 2010; Loftus 2015; Soja 1989), legal studies (Blomley 2003; Butler 2009), and political theory (Purcell 2008; Sassen 2002) continue to draw from Lefebvre's framework as a mechanism towards, in the words of David Harvey, understanding the "ongoing struggles over who gets to shape the qualities of daily urban life" (Harvey 2012, xii). The framework identifies different modalities or "fields" of space that are often implicitly positioned in social theory as containers of action (Lefebvre 1991, 13-14). Instead, Lefebvre argues that these fields are separate but intertwined modes of production. He identifies these fields as spatial practice, representations of space, and representational space. Referred to as a conceptual triad, these spaces are not isolated spheres of production. Rather, each field is informed by the other.

Spatial practice, or lived space, refers to the space of "production and reproduction," the physical, geographically specific locations where action takes place and social order is performed by participants (Ibid., 33). For instance, within a grocery store, production and reproduction occur in ways that are specific to that particular space. Upon entering a store, you might grab a cart or basket, position yourself in an aisle so that others can pass, and then load up a conveyer 
belt to pay for groceries before exiting. Those who enter the store learn, through physical engagement, the norms governing spatial interaction. Spatial practice is where participants perform the quotidian expectations specific to a given environment. These practices are specific to a physical space, but not determined by it. Further, practices may change as expectations of interaction within the space shift.

Representations of space, or conceived space, "are tied to the relations of production and to the order which those relations impose" (33). Lefebvre demarcates this element of the triad as tied to the creation of material order. He writes that this is "the space of scientists, planners, urbanists, technocratic subdividers, and social engineers... all of whom identify what is lived and what is perceived with what is conceived" (38). Framed another way, professionals who craft material and immaterial forms of order, manufacture spatial arrangements out of existing social and physical practices. Representations of space pair knowledge with ideology through abstraction (45). Additionally, this element of the conceptual triad is identified by Lefebvre as the dominant mode of production within society (39). Throughout The Production of Space, Lefebvre critiques representations of space for upholding existing practices of dominant spatial reproduction.

Perceived, or representational space, encompasses symbolism, artistic expression, and meaning-making practices. Lefebvre writes, "this is the dominated-and hence passively experienced-space where imagination seeks to transform and appropriate. It overlays physical space, making symbolic use of its objects"(39). Representational space is dominated but not determined. It is within this mode of production that possibilities for creating different space emerge. Perceived space draws from existing practices and representations to articulate the possibility for the emergence of a different space. This space disrupts the homogeny of the conceived by celebrating the differences that erupt despite the imposed rationality of representations of space (63).

Fundamentally, the conceptual triad identifies the overlapping spatial underpinnings of social and technological forms (404). Identifying and analyzing how infrastructure interacts within these fields of space offers three advantages for scholars within STS. These points will be expanded in greater detail below. First, spaces are not treated as containers for action. Rather different spatial fields are understood as productive of sociotechnical forms. Second, infrastructures, both material and proposed, intersect with all fields of spatial production. Identifying how social relations are structured by these fields reveals how uneven, and at times contradictory, pairings of knowledge and power are produced. Third, attention to space reveals historical articulations of difference, through the production of representational spaces, that sought to disrupt the suggested technological reordering of space.

\section{2 - Infrastructure and Space}

As anthropologist Nikhil Anand described in a recent interview, "infrastructure gives us a site, a place, a set of locations, at which to study" (Menon 2019). The focus on the grounded nature of infrastructure in discrete, yet interconnected, places has inspired a rich literature of scholarship 
attending to governance (Carse 2012), standards (Star and Griesemer 1989), the co-production of social meanings (Kimura 2016; Larkin 2013; Star 1999), and forms of expertise (Harvey and Knox 2015) that emerge in concert with the entrance of technological systems into the built environment. More to the topic of this paper, historians have studied roads and highways to investigate the relationship between science and technology (Seeley 1984), American culture (Lewis 2013), and the landscape (Zeller 2010). Infrastructure, and specifically highways, are often utilized subjects for understanding the social and political relationships made material through infrastructural forms.

Despite the well-documented productive relations between social forms and infrastructural systems, the spaces where those interactions take place are often understood as a container for social and material production (Sheller 2018, 11). Rarely are the spaces that infrastructure comes, or is proposed, to occupy considered as generative of modes of production. Indeed, infrastructural inversion, an oft-utilized STS approach to studying infrastructure, foregrounds the study of technical arrangements as constitutive of power and knowledge (Bowker 1994; Bowker and Star 2000). Infrastructural inversion centers the system as a site of analysis to reveal hidden or invisible material arrangements that come to structure political or social forms (Anand 2011). In this analysis, infrastructure becomes the container where power is made invisible through circuits, nodes, and networks.

Excavating the invisible through the isolation of infrastructure as a site of analysis has produced many important insights. Yet, shifting analysis to the spaces that infrastructure occupies identifies how socio-political arrangements materialized in the first place, as well as calls attention to the differential relationships to knowledge and power that emerge from forms of spatial production. Analyzing the dynamics of infrastructure sitting utilizing Lefebvre's conceptual triad captures how relationships between knowledge and power are produced within and amongst different spatial fields. As the historical case in sections 3 and 4 of this article will demonstrate, some forms of spatial production, such as representations of space, are more dominant in society than others. Yet, without understanding how infrastructurally transitioned space was utilized (practice) or alternative futures of the infrastructural space were imagined (representational space), it is challenging to determine how certain material arrangements of knowledge and power became dominant in the first place.

A final strength of utilizing Lefebvre's conceptual triad in studies of infrastructure is how this analysis foregrounds the unearthing of claims to difference. This focus emerges from the Marxist commitment to restoring the "sensuousness" of human activity as a form separate from mental abstraction or material expression (Marx 1973, 121-123). For Lefebvre, the liberation of the body happens through the creative and symbolic nature of crafting difference. He writes,

The spatial body of society and the social body of needs differ from an 'abstract corpus' or 'body' of signs in the following respect: they cannot live without generating, without producing, without creating differences. To deny them this is to kill them $(1991,396)$. 
To be clear, Lefebvre is referring here to collective labor, a social and thereby shared mode of production fueled by the creation of difference. To deny the social body the labor of crafting difference extinguishes the possibility of liberation. Thus, utilizing the conceptual triad also engages in a political project of exhuming historical articulations of difference that have shaped struggles over space.

\section{3 - Limitations and Critique}

It is necessary to acknowledge a limitation to utilizing the conceptual triad as an analytical framework. Lefebvre's writing is notably unclear about either the utility or analytic conclusions that can be drawn from the conceptual triad. As Andy Merrifield writes, "it's no mechanical framework or typology he's bequeathed but a dialectical simplification, fluid and alive, with three specific moments that blur into each other" $(2006,109)$. Thus, treating the conceptual triad as an analytical framework risks oversimplifying complex spatial phenomena. Yet, the utility of organizing a complex subject, such as the emergence of a contested highway across scale, social forms, and temporal spans, is a useful exercise that may contribute to larger disciplinary understandings of infrastructural complexity and spatial production.

Further, Lefebvre's critique of representations of space, at face value, might appear as dismissive or even incompatible with the broader field of STS. STS as a discipline is often concerned with understanding how claims of material and social order stabilize (Jasanoff and Kim 2009, 124; Jasanoff 2015, 14). By contrast, Lefebvre's understands such stabilization as the dominant means of production in society. Representations of space impose order and rationality with little regard for existing spatial uses or practices. Pushing against such stark technological determinism, scholars such as Derek McCormack, have drawn attention to how STS demonstrates that the technocratic process of spatial abstraction is not always an alienating force, but also generative of new and resistant material practices $(2012,722)$.

Lefebvre's broader critique of representations of space suggests a disinterest in pursuing questions of how claims to order emerge. Instead, he insists on excavating what is ceded when conceived space dominates possibilities for what comes next. Lefebvre calls for working towards, "A different space, towards the space of a different (social) life and of a different mode of production, this project straddles the breach between science and utopia, reality and ideality, conceived and lived" $(1991,60)$. Altering the dominant production of space serves as a practical ideal, as well as a mode of praxis. For the creation of a different space, new modes of production must be imagined.

Within Baltimore, the social production of space played a profound role in both the planning of roadway infrastructures and the organized resistance directed toward this transformation. By proposing new and reimagined uses for the Franklin-Mulberry corridor, city officials and planners vacated the already existing meanings, uses, and values held by the residents who occupied the geographic area of the planned roadway. When neighborhood activists responded to these threats, they crafted a politic that responded directly to administratively rendered notions of their neighborhoods. During the late 1960s and early 1970s, 
a battle between local activists and city officials emerged over the use, meaning, and future of the Franklin-Mulberry corridor itself. The remaining two sections of this essay use Lefebvre's conceptual triad to demonstrate how spatial production informs collective responses, labor, and even the eventual infrastructural form.

\section{3 - Representations of Urban Infrastructural Space}

Representations of space pair knowledge with ideology through abstraction. This section analyzes this structural arrangement in reverse order, beginning with abstraction in the form of two proposed highway plans in Baltimore. Following this discussion, I describe the ideology that supported these plans and how knowledge in the form of quantitative data was used to justify implementation. This arrangement set the stage for future activist engagement and resistance to highway plans.

\section{1 - Two Possible Roads, Two Possible Futures}

Following the passage of an updated city master plan in 1943, a "bitter controversy" tore through Baltimore City (Schaefer 1943). Debates simmering within city planning offices spilled onto the pages of Baltimore's newspaper, The Sun. The argument, which divided planners, residents, and business leaders, concerned the placement of two possible highway routes.

Neither plan necessitated the other. A shortage of fiscal and material resources during World War II led to a civic battle over a local bond issue that could guarantee investment, and thus, the eventual successful completion, of one road over another. The first route proposed constructing a bridge spanning Baltimore's Harbor. This freeway would connect the neighborhoods of Fairfield in the south and Canton to the north, bypassing the city center and effectively routing thru-traffic to the urban fringe. The second route placed a depressed expressway running east and west through the neighborhoods of Harlem Park and Franklin Square. This road aimed to create an efficient route into the city for recently sprawled suburban residents frustrated by long commutes and urban gridlock. Each proposal faced dissent.

A special committee, formed by Mayor Theodore McKeldin, studied the long-term impacts of a freeway to the Harbor and the Port of Baltimore. The committee reported that the fixed height of a bridge may prevent larger ships from utilizing the port in the future. While shipbuilding standards of the day ensured that watercraft would fit under the bridge, the proposed height failed to account for potential innovations in shipbuilding that may require a higher clearance. A bridge curtailed temporally distant uses and growth opportunities. The mayoral committee concluded, "Baltimore should, in our judgment, remain a bridge free port in respect to its principle traffic entrance"(Schaefer 1943). Jeopardizing the future productive capacities of the port, an economic powerhouse both during and before the war, proved too large a risk for the committee.

The east-west expressway faced another set of problems, including the challenging task of acquiring residential and commercial property within the proposed right-of-way. An 
additional concern, voiced by engineers, was how a road would disrupt existing utility lines. As The Sun reports, "telephone, power, gas and water lines can be carried across by being built into the spanning bridge structures. But sewers, most of which are gravity operated will present a special problem" (Opponents End... 1945). The expensive and time-consuming right-of-way acquisition led Philip S. Morgan, a former president of the Baltimore Real Estate Board, to proclaim that, comparatively, the bridge "would cost the city nothing" (Opponents End... 1945).

The possible routes proposed to alter the built environment in distinctly different ways. A harbor bridge bypassed the city, but potentially limited the future economic viability of the Port of Baltimore. The east-west expressway put existing infrastructure at risk, but benefited a monied and growing suburban population just beyond the city's borders. Further, each proposal proffered a certain vision for how the transitioning of space through infrastructural implementation would increase the overall value of the city itself. The harbor bridge could lessen thru traffic within the city, while the expressway would purposely increase the traffic of affluent suburban residents. Each representation of space proposed a new arrangement of Baltimore that when materialized would also represent a novel planning ideology.

\section{2 - The Ideology of a Representation}

To quell the controversy, Mayor McKelden assembled the Harbor Crossing Freeway Committee. Committee member Herbert Brune described the duties of the group as such: "the Committee was requested, first, to name engineering experts whose recommendations from a traffic and engineering standpoint and whose estimates of costs would be impartial and authoritative" (Brune 1944). The committee commissioned Robert Moses, engineer W. Earl Andrews, and a team of consultants hand-picked by Moses from public offices across New York State to undertake this project. By 1944, when he was selected to determine Baltimore's choice of road, Moses had already made a name for himself as a tenacious and powerful planner of parks and highways within New York City (Caro 1975). It was Moses who first paired ideology and knowledge in support of the representation of space that would remake the Franklin-Mulberry corridor.

Urban planners of this era, including Moses, tied the construction of highways or expressways to an ideology in support of a forthcoming modernity. These projections of the future abstracted existing land-use practices in favor of teleological narratives of infrastructural change (Tarr and Konvitz 1992, 214-215). Writing for The Atlantic in 1945, Moses described transportation networks as responsible for the overall decline in urban investment. He writes, "in many cities this process of central decay has been encouraged and speeded up by the building of rapid transit, railroad, road, and other facilities to minutely subdivided farms and estates in outlying sections and the suburbs" (Moses 1945).

This ideology of highways as a "fix" to the social and economic problems of urban space accomplished a duel project. Not only would a direct route from suburb to city encourage travel and tourism, building such a route often necessitated the removal of disinvested properties, described as "slums." In writings, such as the article above, Moses uses "slum" to reference 
overcrowded housing stock, but also to describe geographies populated by economically disenfranchised and racially marginalized populations. Moses suggests building freeways through blighted neighborhoods, thereby allowing suburban populations a pathway to easily and efficiently travel into and out of a city.

Yet, the ideology of roads as determinants of urban decline was patently false. In Baltimore and many other US cities, neighborhood deterioration was an intentional process of systemic dispossession. As Antero Pietila describes in his history of discriminatory housing policies in Baltimore, practices such as redlining and restrictive covenants determined where black and Jewish residents were able to purchase homes (2010). Indeed, as Emily Lieb argues, the persistence of "slum" conditions outside of Baltimore's city center was maintained by a "complex political economy of racism and exploitation" $(2018,94)$. This observation can be extended into debates surrounding road placement. The spaces proposed for transformation, be they residential neighborhoods or port entrances, were always understood as abstract environments. The complexity of the political economy at work was shielded by reductive descriptors such as "slum," "blight," and "decay." In turn, neighborhoods were understood as disordered spaces that would eventually be transitioned into ordered ones upon the introduction of a new highway system.

Moses's impulses toward slum clearance around the urban core were mirrored in Interregional Highways, a 1944 report written by the National Interregional Highway Committee. The report details a plan for the repopulation of cities, specifically central business districts enclosed by blighted properties (Interregional Highways, 53-71). Like Moses, the report understands highways as determinants of the social geography within the city. The report states, "So long, however, as the central areas of the cities are poor places in which to live and rear children, people will move to outskirts. Undoubtedly a factor that has facilitated this movement has been the improvement of highways" (Interregional Highways 54). If roads make possible the dispersion from the center to the periphery, then, the committee presumes, these structures ought to be able to facilitate the opposite.

\section{3 - Knowledge to Support a Representation}

Both Moses's rhetoric and the Interregional Highways report argue in favor of an ideology supportive of a specific transformation of city space replacing "blight" and "slum" conditions with efficient roadways. Yet, this ideology also required utilizing specific types and forms of scientific and technical knowledge in an attempt to garner political support. Moses's 1944 plan, the Baltimore Arterial Report, commissioned by the Harbor Freeway Crossing Committee, merged an ideology supportive of slum clearance into the geography of the Franklin-Mulberry corridor. The representation implicitly links the perceived characteristics of the space (or knowledge of them) with the segregationist ideology described above.

Moses recommended the east-west expressway route over the harbor bridge at the cost of 40 million dollars. The plan required the displacement of over 19,000 people and some 200 city blocks turned to asphalt. Most of the residents affected by this proposal were Black and poor 
(Pietila 2010, 219). In his assessment of the Harlem Park and Franklin Square neighborhoods, Moses writes, "some of the slum areas through which the Franklin Expressway passes are a disgrace to the community and the more of them that are wiped out, the healthier Baltimore will be in the long run" (Moses 1944, 9).

Moses describes the neighborhood of Harlem Park as a natural and rational choice for road placement. The report combines historical traffic data with volume projections of future use, to position the east-west expressway as the most efficient and practical choice for road placement (Moses 1944, 19). Moses's determination utilizes technical and geographic knowledge as justification for a road placement that also accomplishes the dual goal of "slum" clearance. Such positioning also assumes that the space that the expressway would occupy was devoid of productive value. Moses writes in the report: "The Franklin Expressway construction will actually clean out a large number of dwellings that are unfit for use and many others that are substandard. It will, of course, require the elimination of some good buildings, but this is inevitable" (32).

The Harbor-Crossing Freeway Commission disagreed with the overall assessment of the Baltimore Arterial Report. Committee member Herbert Brune questioned how this freeway could help Baltimore "when it poses a mountain of human misery" (Brune 1944). The plan guaranteed that the city would exacerbate an existing housing crisis if the road were to be constructed. Additionally, Baltimore stood to lose a considerable percentage of its tax base, a calculation strangely absent from Moses's "objective" decision. Despite Moses's pairing of ideology and knowledge, the specific representation of space he advanced failed to be recognized as a politically viable option for the city. In the end, the commission failed to support the plan.

Yet, as the existence of the highway to nowhere suggests, the commission's decision did not end the push to build an arterial route into the city. Even though the committee rejected the plan, the Baltimore Arterial Report created a framework and justification for developing a roadway that displaced thousands in support of suburban convenience. As the push to build urban highways increased in the 1950s and 1960s, activists in Baltimore responded directly to the representations of space first articulated in the report that saw their neighborhoods as devoid of value. By establishing the value of existing social practices and crafting different visions for the transformation of their neighborhoods, activists challenged the persistent pairing of ideology and knowledge that threatened their ability to make claims to urban space.

\section{4 - Relocation Action Movement and Spatially Informed Activism}

Representations of space concerning the Franklin-Mulberry Corridor persisted into the 1960s and 1970s as states sought to acquire funding associated with the Federal-Aid Highway Act. This renewed interest in highway building encouraged city officials to support road-building activities and inspired social resistance termed "freeway revolts" (Mohl 2008). This section examines how activists from neighborhoods affected by the development of the Franklin-Mulberry corridor challenged the ideology and knowledge that undergirded representations of the spaces. This 
resistance drew from established spatial practices and representational visions of how space might be imagined differently.

\section{1 - Different Spaces, Different Social Forms}

The Federal-Aid Highway Act of 1956 allocated about 25 billion dollars toward the construction of interstate highways and freeways in the US. Under this legislation, local municipalities paid $10 \%$ of the highway building costs with the federal government covering the other $90 \%$ (Rose and Mohl 2012, 89). These incentives encouraged civic leaders and representatives nationwide to write new or implement long-awaited road proposals that could qualify their districts for allocations of federal funds. The windfall of money also became a way to rebuild within urban areas. These plans often faced a public outcry. As Rose and Mohl write, "the consequence of state and local route selection was that urban expressways could be used specifically to carry out local racial, housing, and residential segregation agendas" (97). These divides produced nation-wide resistance to planning efforts, often called "freeway revolts."

Baltimore experienced a ground swell of civic activism concerning the proposed highway. The group most noted for their efforts was Movement Against Destruction (MAD). MAD was a diverse coalition group, consisting of member organizations and individuals from across the city (Membership - Member Organizations, 9; Gioielli 2014; Mohl 2004, 698). These members represented heterogeneous perspectives on how, or even whether, a highway should be built. MAD initially advocated for "comprehensive" transportation planning that included housing improvement, mass transit options, and joint development opportunities (Minutes 1968, 18-19).

Other organizations, such as The Society for the Preservation of Federal Hill and Fells Point (The Society) and Volunteers Opposing Leakin Park Expressway (VOLPE) forcefully opposed the construction of highway segments that would impact the neighborhood or park they represented. The social and geographic diversity of participant groups did not signal the integration of spatially disparate perspectives. Robert Gioielli makes this clear: "an interracial movement to prevent the highway was unique, but activists were driven more by the fractured and segregated realities of an industrial city than by a liberal integrationist or radical utopian ideology" (2011, 65). Furthermore, the fracturing of activist groups by neighborhood or other geographically defined space points to the multiple scales of spatial production.

Before the formation of MAD and other highway oriented organizations, Relocation Action Movement, or RAM, began organizing in the neighborhoods threatened by the proposed Franklin-Mulberry corridor. RAM insisted upon the right to remain in the city following residential displacement. The spatially defined context of RAM's activism offers the unique opportunity to examine socio-spatial production at the neighborhood scale. Specifically, RAM's activism points to an important intersection within Lefebvre's conceptual triad-how spatial practices and representational space are simultaneously dominated by and responsive to the exclusion imposed by representations of space. Furthermore, RAM's work demonstrates how urban space can be imagined differently, outside of the narrow visions of technical experts. This 
articulation of representational space, emerging from existing practices and dominant representations of space, demonstrates how a community envisioned the creation of a different space, and ultimately, an alternative material future.

\section{2 - Spatial Practice and the Creation of Knowledge}

RAM began organizing following the issuing of condemnation orders for houses within the Franklin-Mulberry Corridor in 1966 (Giguere 2009, 114). These orders were the first step by the city to displace residents to begin construction on the expressway. By this point in time, Baltimore officials sought to construct an interstate system that would qualify for federal funds. While the exact route shifted frequently, the broad proposal involved an arterial road that would approach the city from the east and west, linking to suburban outposts and connecting to the city core (Wong 2013). City officials targeted the Franklin-Mulberry corridor segment of this system as one of the initial phases for construction.

Many members of RAM resided in the Harlem Park neighborhood, a lower-class enclave of mostly Black residents, or the more middle class, "stable," Rosemont neighborhood (Lieb 2010, 138). Both neighborhoods were heavily impacted by the condemnation ordinance. RAM collected data about the neighborhood to establish existing spatial practices. For instance, RAM gathered statistics of homeownership within the corridor, demonstrating that despite civic neglect, close to $50 \%$ of the houses in the area were still owned by residents. In Rosemont, the owner-occupancy rate was even higher at 72\% (Expressway Walking Tour, 7). An additional one-hundred people were on waiting lists for public housing in the neighborhoods impacted by the proposed expressway (Rosemont, 9). In meetings with city council members and the mayor, these measures demonstrated the marks of an active community—a high percentage of homeowners and a desire for residents to remain in the area. These spatial practices, the day-to-day production within neighborhoods, signaled to officials that Harlem Park and Rosemont were not devoid of either economic or social value.

Additionally, organizers argued that placing the route through Rosemont was a deliberate attempt to fracture or destroy Baltimore's black middle-class community. To build the road also required extinguishing the practices that knit the neighborhood together. This point was glaring as the proposed route deliberately bypassed a nearby cemetery (3). RAM asserted that the elimination of impoverished areas in the name of infrastructural progress meant dispossessing residents of their claim to neighborhood space. Indeed, the existing spatial practices of residents challenged the segregationist ideology guiding development. Neighborhoods within the corridor were desirable and active city spaces that contained properties and businesses that supported the larger city.

The group stressed that residents were not being fairly compensated for their physical relocation and were being asked to sacrifice their place in the city altogether. Mourning this loss, organizers wrote, "this expressway was uprooting them from their own homes and leaving them stranded without enough money to purchase another home in a city which does not provide for the adequate rehousing of its relocated citizens" (Relocation Action Movement, 3). The 
condemnation orders delivered a sense of erasure to residents before any physical development. To accept the freeway meant the loss of one's home, the ability to continue to reside in the city, to associate with neighbors, and to remain a part of the communities they had built. The potential loss of social and spatial claims in the wake of the highway also inspired radical and imaginative claims to retain these relationships.

\section{3 - The Power in Crafting Representational Space}

In a meeting with the Governor of Maryland, Spiro Agnew, in the winter of 1968, RAM argued against the condemnation orders by demonstrating the deliberate segregation imposed through infrastructural policy. The argument became one of justice predicated on the right to live within, support, and make claims to urban space.

For too long the history of Urban Renewal and Highway Clearance has been marked by the repeated removal of black citizens. We have been asked to make sacrifice after sacrifice in the name of progress, and when that progress has been achieved we find it marked "White Only" (6).

RAM voiced a direct relationship to the ideas of progress, the representational idiom put forth in the interstate project, and the politics of spatial exclusion. Later in the meeting, activists presented a proposal to build a highway that centered the practices, value, and productive capacities of the Franklin-Mulberry Corridor. This proposal situated the cost-benefit-analysis practices of city engineers and urban planners as an ideology supportive of segregationist policies (9).

In turn, RAM demanded that planners alter their calculations. Rather than conceiving of the expressway as creating value in an otherwise valueless area, activists demanded that planners reassess neighborhoods as containing an economic and social value. For instance, activists argued that the assessment of a condemned houses' value ought to be calculated at a pre-highway proposal market value. This appraisal would acknowledge the history of intentional civic disinvestment in the corridor, while also providing enough compensation for residents to relocate without any undue financial burden (8). By demanding that planners take into account different metrics in condemnation and relocation decisions, activists demanded a different representational space. To phrase this another way, activists crafted a different future for their neighborhoods by drawing attention to the material effects of segregationist pairings of knowledge and power within road plans.

The crafting of spatial difference in response to imposed representations of space also emerged in larger organizational goals. For instance, stopping road-building efforts did not factor heavily into the aims of RAM. At times, this stance put RAM members at odds with other highway-focused organizations in the city (Minutes - Part 1 1969, 72). Instead, the group configured itself as obstructive until fair compensation was guaranteed. Nowhere is this more evident than in the position taken by the organization that "unless those being victimized are 
treated like human beings, 'NO EXPRESSWAY WILL PASS THROUGH OUR CITY!!!'”(Relocation Action Movement, 1). RAM claimed community ownership of the spaces its members occupied. The rhetoric and policy alternatives put forth by RAM asserted that the people, homes, communities, and cultures within the threatened Franklin-Mulberry corridor contained value through the existing spatial practices of its residents. Furthermore, the group demanded recognition as a collective that was differentially impacted by the road plans.

RAM also asserted that a highway built in the city should serve the communities through which it passes, rather than suburban commuters. The different highway would be built to occupy a representational space where residents had more agency in how the city was transformed. Proposals to enact these practices included the prioritization of Black and local contractors in the awarding of expressway contracts, job-training programs to staff construction projects, and the development of integrated mass transit options alongside expressway infrastructure (14-15). RAM's intervention asserted a vision of the different future that envisioned new possibilities for the material organization of the environment. The group acknowledged how administrative representations of space impacted their history, mission statements, and larger activism. Indeed, without the condemnation orders, the highway proposals, and the civic disinvestment, the group would not have organized. But more substantially, RAM's work demonstrates how the occupation of the physical landscape can be a catalyst to imagine different futures-ones where both road and resident coexist.

RAM's political activities suggest the group was conscious of the spatial effect of the proposed highway infrastructure. Activists challenged not just the road, but more specifically the perceived understandings of space possessed by engineers and planners. RAM suggested an alternative infrastructural future, a collective claim to space imagined differently. In this idiom, spaces ceased to be slums and instead became contested and valuable. In turn, highway developers then needed to account for the voices, bodies, and properties RAM articulated as valued.

By demonstrating how roadway infrastructure worked as a mechanism of deletion, the group brought visibility to exclusionary policies made in the name of progress and modernity. The group proved successful in some of its goals. As Andrew Giguere writes, "RAM managed to influence the creation of a state law that would compensate displaced individuals with not only money to cover the replacement value of their homes, but also a subsidy of up to $\$ 5,000$ to help homeowners cover the cost of moving" $(2009,125)$. However, these victories, although situated within the wider social ecology of Baltimore's highway resistance, ultimately paved the way for the highway to nowhere.

\section{5 - Conclusion}

Ground was broken on the corridor following the defeat of a lawsuit brought by MAD challenging the legality of the whole highway plan. As The Sun reported, "the city was so eager to begin construction in the Franklin-Mulberry corridor in June 1973, that the bulldozers were at work within hours of a United States District Court decision allowing the expressway work to 
proceed" (Dilts 1975). Battles against different segments of the interstate highway persisted across Baltimore well into the late 1970s. Legal victories by the Sierra Club and VOLPE halted the construction of the western connecter segment. This decision ultimately led the city to cease development on many other interstate segments (Mohl 2004, 697). The highway, in its current form, stands as a far cry from the dreams of the well-managed traffic envisioned by Moses or the mass transit-friendly roadway suggested by RAM. Although the highways of Baltimore City look nothing like other urban expressways, the incomplete and disjointed system forms an infrastructure deeply intertwined with historical modes of spatial production.

The highway to nowhere, for some, was the kernel of a collective good. Building the road would catalyze urban change, reinvestment, and development. Yet, this spatial transformation proved profoundly fragile, bolstered only by legacies of racist urban policies and systemic dispossession. By examining the relationships between the administrative representations of space, the lived residential experiences of discrimination and displacement, and the different spaces activists imagined possible through infrastructural change, the potency of examining infrastructure using Lefebvre's triad of spatial production emerges. If we were to look back to the construction of the "highway to nowhere" only through the lens of the proposed spatial transformation, RAM's hard-fought battle risks erasure. By foregrounding space in accounts of how visions of a technological future emerge, we can better describe the spatial production that undergirds infrastructural construction. Understandings, interpretations, and uses of space profoundly impact how social formations organize, respond, and craft modes of political praxis. Negating space glosses over this richness.

Lefebvre's larger project in developing his understanding of space was a political one. He writes, "A social transformation, to be truly revolutionary in character, must manifest a creative capacity in its effects on daily life, on language and on space" (Lefebvre 1991, 54). This article has broadly argued that radical visions of social and technological change emerge out of the different forms of spatial production. Further, utilizing Lefebvre's conceptual triad within in STS-based approaches to infrastructure offers a way to understand the additive and contradictory forms of spatial production that shape our ordered world.

In turning attention to how space is perceived, conceived, and lived, we might better understand not only the history of how certain technological and social forms came to be, but also suggest how we might envision these forms changing. Infrastructures have material footprints that step across time. The deep racial, social, and economic divides of contemporary Baltimore demonstrate this persistence (Grove et al. 2017). Yet, the work of RAM points to the collective power in foregrounding the needs of specific spaces within demands for a better technological future. In a time when both social and material infrastructures are increasingly acknowledged to cause or perpetuate harm, it is the perfect moment to consider how the social production of space might inform our visions of a new infrastructural future, one more just and equitable than previously assembled. 


\section{Author Biography}

Amanda K. Phillips de Lucas is a Postdoctoral Research Associate at the Cary Institute of Ecosystem Studies. She is currently investigating emerging practices of stakeholder governance in cities implementing green stormwater infrastructure. Amanda received her Ph.D. in Science and Technology Studies from Virginia Tech in 2018.

\section{Acknowledgements}

I would like to thank Daniel Breslau, Barbara Allen, Jim Collier, Richard Hirsch and the larger STS community at Virginia Tech. Steward Pickett and J. Morgan Grove provided invaluable comments, suggestions, and an environment supportive of intellectual curiosity as I wrote this essay. The article was strengthened in revisions through feedback from ESTS editors and anonymous reviewers.

\section{References (Published Sources)}

Anand, Nikhil. 2011. "Pressure: The Politechnics of Water Supply in Mumbai." Cultural Anthropology 26 (4): 542-64. https:/ / doi.org/10.1111/j.1548-1360.2011.01111.x.

Brown, Lawrence. 2015. "Down to the Wire: Displacement and Disinvestment in Baltimore City." In The 2015 State of Black Baltimore: Still Separate, Still Unequal. Greater Baltimore Urban League.

Blomley, Nicholas. 2003. "Law, Property, and the Geography of Violence: The Frontier, the Survey, and the Grid." Annals of the Association of American Geographers 93(1): 121-41. https: / / doi.org/10.1111/1467-8306.93109.

2010. "Cuts, Flows, and the Geographies of Property." Law, Culture and the Humanities 7(2): 203-16. https: / / doi.org/10.1177 / 1743872109355583.

Bowker, Geoffrey C. 1994. Science on the run: Information management and industrial geophysics at schlumberger, 1920-1940. Cambridge, MA: MIT Press.

Bowker, Geoffrey C, and Susan Leigh Star. 2000. Sorting Things Out: Classification and Its Consequences. Cambridge, MA: MIT Press.

Butler, Chris. 2009. "Critical Legal Studies and the Politics of Space." Social and Legal Studies 18 (3): 313-32. https: / / doi.org/10.1177 / 0964663909339084.

Caro, Robert. 1975. The Power Broker: Robert Moses and the Fall of New York. New York, NY: Vintage Books.

Carse, Ashley. 2012. "Nature as Infrastructure: Making and Managing the Panama Canal Watershed." Social Studies of Science 42 (4): 539-63, https: / / doi.org/10.1177/0306312712440166.

Giguere, Andrew M. 2009. “'....and Never the Twain Shall Meet': Baltimore's East-West Expressway and the Construction of the "Highway to Nowhere.'" Dissertation: Ohio University. 
Gioielli, Robert R. 2011. “'We Must Destroy You to Save You': Highway Construction and the City as a Modern Commons." Radical History Review 2011 (109): 62-82. https:// doi.org/10.1215/01636545-2010-015. 2014. Environmental Activism and the Urban Crisis: Baltimore, St. Louis, Chicago. Temple University Press.

Grove, Morgan, Laura Ogden, Steward T.A. Pickett, Christ Boone, Geoff Buckley, Dexter Locke, Charlie Lord, and Billy Hall. 2017. "The Legacy Effect: Understanding How Segregation and Environmental Injustice Unfold over Time in Baltimore." Annals of the American Association of Geographers, 108(2), 524-537. https: / / doi.org/10.1080/24694452.2017.1365585

Harvey, David. 2012. Rebel Cities: From the Right to the City to the Urban Revolution. New York, NY: Verso.

Harvey, Penny, and Hannah Knox. 2015. Roads: An Anthropology of Infrastructure and Expertise (Expertise: Cultures and Technologies of Knowledge). Ithaca, NY: Cornell University Press.

Jasanoff, Sheila. 2015. "Future Imperfect: Science, Technology, and the Imaginations of Modernity." In Dreamscapes of Modernity: Sociotechnical Imaginaries and the Fabrication of Power, edited by Sheila Jasanoff and Sang-Hyun Kim, 1-33. Chicago, IL: Chicago University Press.

Jasanoff, Sheila, and San-Hyun Kim. 2009. "Containing the Atom: Sociotechnical Imaginaries and Nuclear Power in the United States and South Korea." Minerva 47 (2): 11946. https:// doi.org/10.1007/s11024-009-9124-4.

Kimura, Shuhei. 2016. "When a Seawall Is Visible: Infrastructure and Obstruction in Post Tsunami Reconstruction in Japan." Science as Culture 25 (1): 23-43, https: / / doi.org/10.1080/09505431.2015.1081501.

Larkin, Brian. 2013. "The Politics and Poetics of Infrastructure." Annual Review of Anthropology 42 (1): 327-43, https: / / doi.org/10.1146/annurev-anthro-092412-155522.

Lefebvre, Henri. 1991. The Production of Space. Maiden, MA: Blackwell Publishers.

Lewis, Tom. 2013. Divided Highways: Building the Interstate Highways, Transforming American Life. Ithaca, NY: Cornell University Press.

Lieb, Emily. 2010. "Row House City: Unbuilding Residential Baltimore, 1940-1980." Dissertation: Columbia University.

2018. "'Baltimore Does Not Condone Profiteering in Squalor': The Baltimore Plan and the Problem of Housing-Code Enforcement in an American City." Planning Perspectives 33 (1): 75-95. https: / / doi.org/10.1080/02665433.2017.1325774.

Light, Jennifer. 2009. The Nature of Cities: Ecological Visions and the American Urban Professions, 1920-1960. Baltimore, MD: Johns Hopkins University Press.

Locke, Dexter, Billy Hall, J M. Grove, Steward T. Pickett, Laura A. Ogden, Carissa Aoki, Christopher G. Boone, et al. 2020. "Residential Housing Segregation and Urban Tree Canopy in 37 US Cities." SocArXiv. January 6. https:/ / doi.org/10.31235/osf.io/97zcs.

Loftus, Alex. 2015. "Violent Geographical Abstractions." Environment and Planning D: Society and Space 33(2): 366-81. https:/ / doi.org/10.1068/d14120p. 
Marx, Karl. 1973. "Theses on Feuerbach." In The German Ideology: Part One, edited by C.J. Arthur, 121-23. New York, NY: International Publishers.

McCormack, Derek. 2012. "Geography and abstraction: Towards an affirmative critique." Progress in Human Geography 36(6): 715-734. https: / / doi.org/10.1177/0309132512437074.

Menon, Siddhartha. 2019. "Infrastructure's Inequalities: A Conversation with Nikhil Anand and Nausheen Anwar." Edge Effects. Accessed 21 Jan. 2020. https://edgeeffects.net/anandanwar-infrastructures/.

Merrifield, Andy. 2006. Henri Lefebvre: A Critical Introduction. New York, NY: Routledge.

Mohl, Raymond A. 2004. "Stop the Road: Freeway Revolts in American Cities." Journal of Urban History 30 (5): 674-706. https: / / doi.org/10.1177/0096144204265180.

2008. "The Interstates and the Cities: The U.S. Department of Transportation and the Freeway Revolt, 1966 - 1973." Journal of Policy History 20 (2): 193-226. https: / / doi.org/10.1353/jph.0.0014

Pietila, Antero. 2010. Not in My Neighborhood: How Bigotry Shaped a Great American City. Chicago, IL: Ivan R. Dee.

Purcell, Mark. 2008. Recapturing Democracy: Neoliberalization and the Struggle for Alternative Urban Futures. New York, NY: Routledge.

Rose, Mark H., and Raymond Mohl. 2012. Interstate: Highway Politics and Policy Since 1939. Third. Knoxville, TN: University of Tennessee Press.

Sassen, Saskia. 2002. "The Repositioning of Citizenship: Emergent Subjects and Spaces for $\begin{array}{lllll}\text { Politics." Berkeley Journal of } & \text { Sociology } & \text { 46: }\end{array}$ https: / / doi.org/10.1080/14747730500085114.

Seely, Bruce. 1984. “The Scientific Mystique in Engineering: Highway Research at the Bureau of Public Roads, 1918-1940." Technology and Culture 25 (4): 798-831. https:// doi.org/10.2307/3104623.

Sheller, Mimi. 2018. Mobility Justice: The Politics of Movement in an Age of Extremes. London, UK: Verso.

Soja, Edward W. 1989. Postmodern Geographies: The Reassertion of Space in Critical Social Theory. London, UK: Verso.

Star, Susan Leigh. 1999. "The Ethnography of Infrastructure." American Behavioral Scientist 43 (3): 377-91, https: / / doi.org/10.1177/00027649921955326.

Star, Susan Leigh, and James R. Griesemer. 1989. “Institutional Ecology, 'Translations' and Boundary Objects: Amateurs and Professionals in Berkeley's Museum of Vertebrate Zoology, 1907-39." Social Studies of Science 19 (3): 387-420, https://doi.org/10.1177/030631289019003001.

Tarr, Joel A., and Josef W. Konvitz. 1987. "The Evolution of American Urban Technology." In American Urbanism: A Historiographical Review, edited by Howard Gillette and Zane Miller. New York: Greenwood Press. 
Wong, Sidney. 2013. "Architects and Planners in the Middle of a Road War: The Urban Design Concept Team in Baltimore, 1966-71." Journal of Planning History 12 (2): 179-202. https:// doi.org/10.1177/1538513212471167.

Zeller, Thomas. 2010. Driving Germany: The Landscape of the German Autobahn, 1930-1970. Berghahn Books.

\section{References (Archival Sources)}

Brune, Herbert M. 1944. "Analysis of Freeway Proposal, 1944-10-11". Movement Against Destruction Records; Series VII, Box 7A, Folder 1; University of Baltimore Special Collections and Archives.

Dilts, James D. 1975. "Franklin-Mulberry Highway's Cost is Double 1972 Estimate." The Sun (1837-1994), 01 Oct, 2; ProQuest Historical Newspapers: The Baltimore Sun pg. C24.

“Expressway Walking Tour 1970-."1970. Movement Against Destruction Records; Series 2, Box 2, Folder 17. University of Baltimore Special Collections and Archives.

“Membership-Member Organizations, 1970-1975." 1970. Movement Against Destruction Records; Series 1, Box 1, Folder 20. University of Baltimore Special Collections and Archives.

“Minutes 1968." 1968. Movement Against Destruction Records; Series 1, Box 1. Folder 5. University of Baltimore Special Collections and Archives.

“Minutes - Part 1: 1969-01-1969-06," 1969. Movement Against Destruction Records; Series 1, Box 1. Folder 6. University of Baltimore Special Collections and Archives.

Moses, Robert M. 1944. "Baltimore Arterial Report," SASB M2 - Milstein Division - Room 121 New York Public Library.

. 1945. "Slums and City Planning." Atlantic Monthly. (Jan): 63-68. Accessed 1 July 2019. https: / / www.theatlantic.com/magazine/archive/1945/01/slums-and-cityplanning/306544/.

“OPPONENTS END FREEWAY FIGHT: CITY COUNCIL CHAMBER IS PACKED FOR HEARING." 1945. The Sun (1837-1993); 28 March; ProQuest Historical Newspapers: The Baltimore Sun pg. 14.

“Relocation Action Movement." 1968. Movement Against Destruction Records; Series 7, Box 7, Folder 105. University of Baltimore Special Collections and Archives.

“Rosemont." 1969. Movement Against Destruction Records; Series 1, Box 1. Folder 32. University of Baltimore Special Collections and Archives.

Schaefer, J.W. 1943. "Harbor Bridge Plan Shortly Up To City." The Sun (1837-1993); 19 Dec. ProQuest Historical Newspapers: The Baltimore Sun pg. SM1.

United States. National interregional highway committee. 1944. Interregional highways: Message from the President of the United States, transmitting a report of the National interregional highway committee, outlining and recommending a national system of interregional highways, Washington: U.S. Govt. print. off. 